ISSN 1392-3196 / e-ISSN 2335-8947

Zemdirbyste-Agriculture, vol. 100, No. 2 (2013), p. 213-219

DOI 10.13080/z-a.2013.100.028

\title{
Spatial variability of some soil properties: a case study of the Lower Seyhan river basin in Turkey
}

\author{
Tülay TUNÇAY ${ }^{1}$, İlhami BAYRAMIN ${ }^{2}$, Abdullah ERHAN TERCAN ${ }^{3}$, İlhami ÜNVER ${ }^{2}$ \\ ${ }^{1}$ Ankara University, Earth Sciences Application and Research Center \\ Ankara, Turkey \\ E-mail: tuncay@agri.ankara.edu.tr \\ ${ }^{2}$ Ankara University, Department of Soil Science and Plant Nutrition \\ Ankara, Turkey \\ ${ }^{3}$ Hacettepe University, Department of Mining Engineering \\ 06800 Ankara, Turkey
}

\begin{abstract}
The aim of this study was to evaluate the performance of a closed drainage system in one area of the Lower Seyhan river basin in Cukurova, Turkey by measuring spatial variations in soil characteristics. Seven parallel transects which had a $150 \mathrm{~m}$ length were selected at $5 \mathrm{~m}$ intervals within the study area, and 104 soil samples were collected and analysed for soil $\mathrm{pH}$, electrical conductivity (EC), exchangeable sodium (Na) content and exchangeable sodium percentages (ESP). Results were subjected to inverse distance weighting (IDW) interpolation. EC, $\mathrm{pH}$ and ESP estimates obtained from IDW interpolation were compatible with the results of soil analysis. Cross validation was performed to determine the accuracy of the interpolation technique. Interpolation of EC values showed a high mean error in $120-150 \mathrm{~cm}$ depth $(9.010 \%)$, which was attributed to poor drainage conditions. Minimum sample number, maximum sample number, maximum radius and power were found to have an influence on the accuracy of IDW interpolation. ESP, exchangeable $\mathrm{Na}$, EC values were generally low for shallow soil horizons, with values increasing with increases in depth. Data sets were analyzed with two-way ANOVA (the factors were six pipe regions (1-6) and five soil depths $(30,60,90,120,150 \mathrm{~cm}))$ and means compared with Duncan's multiple range test. It was found that the efficiency of drainage pipe, in regions 1, 2, 3 and 4 can diminish rather than the other pipe regions.
\end{abstract}

Key words: closed drainage system, Çukurova (Turkey), inverse distance weighting, spatial variability.

\section{Introduction}

Site-specific management (SSM) has received considerable attention based on its potential to increase input efficiency, improve economic margins of crop production and reduce environmental risks (Redulla et al., 1996). The analysis and interpretation of spatial variability of soils is a key element in site-specific farming.

Geostatistical methods can provide reliable estimates at unsampled locations (Kerry, Oliver, 2004). Two of the most commonly used interpolation methods for SSM are IDW and kriging (Kravchenko, Bullock, 1999). IDW has been used primarily because it is simple and quick, whereas kriging, although more complex and time-consuming, is considered to provide the best unbiased linear estimates. The literature contains numerous mathematical descriptions of both these methods (Weber, Englund, 1992; Hosseini et al., 1994; Gotway et al., 1996; Nalder, Wein, 1998; Kollias et al., 1999; Kravchenko, Bullock, 1999; Schloeder et al., 2001; Kravchenko, 2003; Panagopoulos et al., 2006; Lu, Wong, 2008; Wenjio et al., 2009.

There have been many conflicting reports concerning the use of interpolation methods and their parameters. Whereas some studies have found the performance of kriging to be, in general, better than that of IDW (HHosseini et al., 1994; Kravchenko, Bullock, 1999), others have reported IDW to be more accurate than kriging (Weber, Englund, 1992; Nalder, Wein, 1998).

Cross validation is a common practice used to validate the accuracy of an interpolation (Voltz, Webster, 1990) and also is excellent scheme for solving the inconvenience of redundant data collection (Olea, 1999; Webster, Oliver, 2001). Cross validation is obtained by eliminating one observation from the data set, estimating the value at that location with the remaining data, and then computing the difference between the actual and observed values for the data location (Robinson, Metternicht, 2005). This study conducted cross validation using the Pronet software program.

In view of the conflicting results reported by previous studies, this study aimed to identify the spatial variability of various soil parameters in the study area and to evaluate the accuracy of IDW interpolation in determining the values for these parameters due to poor sample points around study area. This would enable the identification of areas where remediation is required to improve crop growth, and land management process. 


\section{Materials and methods}

Study area. This study was carried out in the Lower Seyhan river basin, an alluvial plain located in southern Turkey. The study area was comprised of 104 ha of irrigated agriculture land within a multi-directional drainage system (WGS84; 679312-681014 E, 4079399$4081100 \mathrm{~N}$ ) (Fig. 1). The climate of the study area is Mediterranean, with a mean average annual temperature

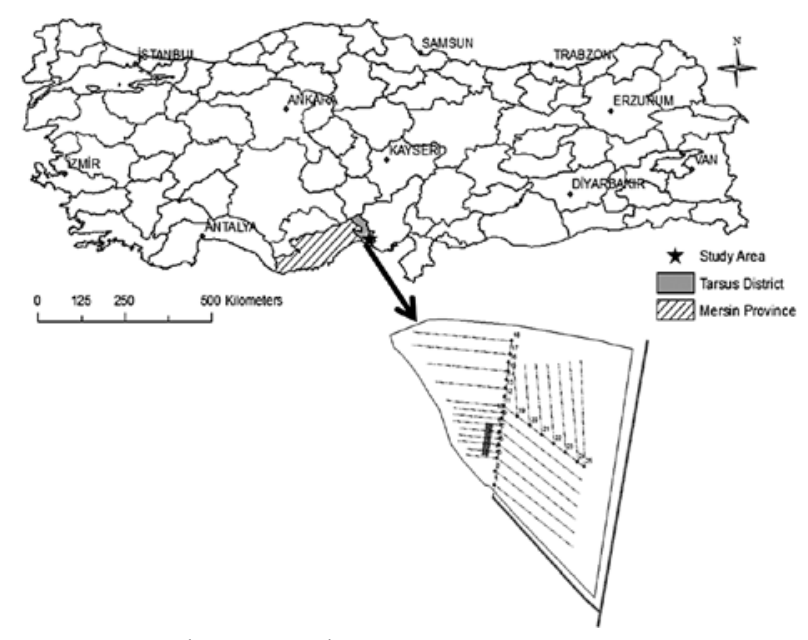

Figure 1. The research area

Soil in the Lower Seyhan river basin is formed from sediment conveyed from the Toros mountains to Tarsus by the Seyhan river, resulting in heavily stratified sedimentation. The upper layer of soil in the study area was formed from alluvial material in the Quaternary age and consists mainly of clay, with some sand and silt. Despite poor slope and drainage characteristics, following the completion of a drainage system and land remediation in the early 1960s, a satisfactory level of plant cultivation was established (Kumova, Yarpuzlu, 1987).

In the project area, drainage studies were started in 1963 and completed in 1988. The project area occupies 104 ha agricultural land. Four different drainage patterns were established in the project area. Drainage pipe diameters and pipe installation intervals were $5 \mathrm{~cm}-30 \mathrm{~m}, 8 \mathrm{~cm}-60 \mathrm{~m}, 10 \mathrm{~cm}-80 \mathrm{~m}$ and $15 \mathrm{~cm}-60 \mathrm{~m}$, respectively. These drainage patterns were shown in Figure 2. Drainage pipes consist of polyvinyl chloride (PVC), and are surrounded by a gravel envelope with design depth of $1.4 \mathrm{~m}$. All of the drainage pipes were connected to main collector, which was established from north to south, and drainage waters were conveyed to major open drainage channel using this collector. During drainage system construction, twenty-five observation wells were established (Fig. 2). During field observation in rainy seasons (November and December) some poundings and drainage problems were determined especially in the $5 \mathrm{~cm}-30 \mathrm{~m}$ drainage pipe interval pattern. The drainage system is also used as an irrigation system by the residents of Alifak1 village, who graze their animals in the area (Tunçay, 2010).

Seven parallel transects of $150 \mathrm{~m}$ in length were designated at $5 \mathrm{~m}$ intervals within the study area. In total, 104 soil samples were collected at different soil horizons from 24 different points $\left(0,50,100\right.$ and $150 \mathrm{~m}$ in the $1^{\text {st }}$, $3^{\text {rd }}, 5^{\text {th }}$ and $7^{\text {th }}$ transects; at 25,75 and $125 \mathrm{~m}$ in the $2^{\text {nd }}$ and $6^{\text {th }}$ transects; and at 50 and $100 \mathrm{~m}$ in the $4^{\text {th }}$ transect). The coordinates of each sampling location were recorded using a differential global position system (DGPS). of $19^{\circ}$ and a total annual precipitation of $583 \mathrm{~mm}$, according to the Turkish State Meteorological Service. Based on data from 1975-2008, the study area was classified according to Thornthwaite (1948) as a semiarid, mesothermal ( $\left.\mathrm{B}^{\prime} 3\right)$ marine climate with a large winter water surplus, a xeric soil-moisture regime and a mesic temperature regime.

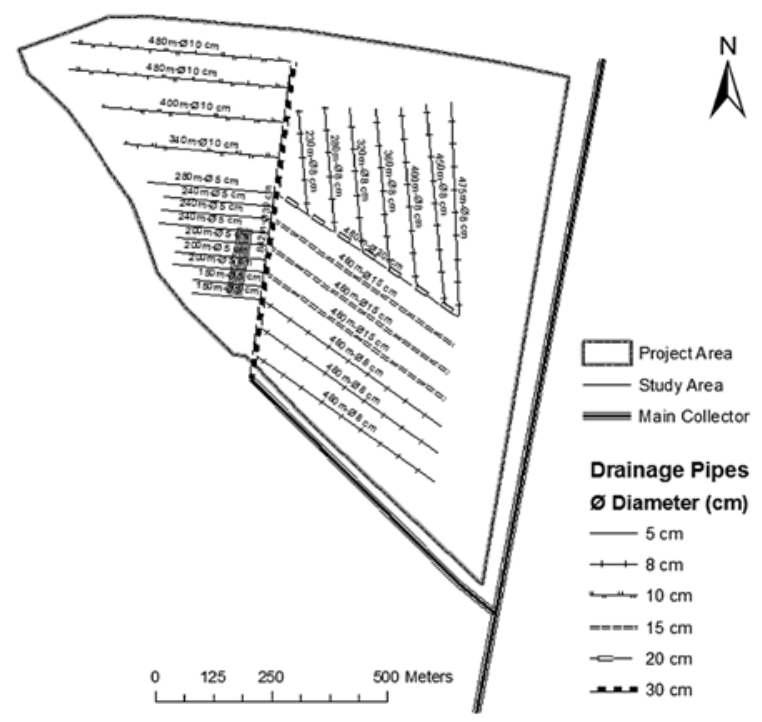

Figure 2. Drainage pattern of the study area

Sampling design. The study area is located on the alluvial plain, and it is very well known that spatial variability of the soil properties change in short distance on alluvial soils. To determine spatial variability of the soil parameters (such as pH, EC, ESP, exchangeable $\mathrm{Na}$ content, etc.) and drainage efficiency, vertical and horizontal experimental design was selected for soil sampling (Fig. 2). Soil pH, EC, exchangeable Na, ESP are important soil properties which have a devastating effect on soil productivity. Soil samples were analyzed for $\mathrm{pH}, \mathrm{EC}$ and exchangeable Na content. These results were evaluated by inverse distance weighting (IDW) using the GemcomSurpac 3D software program. For each sample point, soil samples were taken to depth of $150 \mathrm{~cm}$ and used to produce five different soil layers depth (from 30 to $150 \mathrm{~cm}$ ) maps for each property and parameter $p(p ; 2)$. The precision and performance of IDW are affected by the number of known samples used for estimation. In this study, the number of close sample locations was fixed at 24 , and each soil sample point was evaluated at 4-5 soil horizons, depending upon soil classification. A total of 104 soil samples were collected at 24 soil samplings from each soil horizon at the study area.

Soil samples were gathered individually and packed into boxes, air dried, crushed and sieved ( $2 \mathrm{~mm})$. Mixtures of 1:2 soil to pure water were prepared, and $\mathrm{pH}$ and $\mathrm{EC}$ were measured using a $\mathrm{pH}$ electrode. Exchangeable sodium percentages (ESP) analysis is a measure of exchangeable charges per unit of soil as expressed using $\mathrm{NH}_{4} \mathrm{OAc}$ and a $\mathrm{pH}$ of 7.0 (Thomas, 1982). In this study, ESP was calculated using exchangeable Na values.

Spatial prediction methods. Interpolation techniques. IDW is commonly used to map soil properties in agricultural areas (Weber, Englund, 1992; Franzen, Peck, 1995; Gotway et al., 1996), and the interpolation procedures are clearly explained in the literature (Laslett et al., 1987; Kravchenko, Bullock, 1999). IDW is one of a number of local deterministic methods of interpolation that operates directly on the assumption that the value 
of an attribute at an unsampled location is that of a weighted average of the known data points within a local neighborhood surrounding the unsampled location (Burrough, McDonnell, 1998). Estimated values are interpolated based on the data from surrounding locations using the formula:

$$
Z \times(x o)=\sum_{i=1}^{n} w i Z(x i)
$$

where wi is the weight assigned to the value at each location $Z\left(\chi_{i}\right), n$ - the number of close neighboring sampled data points used for estimation.

Weights are established using the formula:

$$
w i=\frac{1 / d_{i}^{p}}{\sum_{i=1}^{n} 1 / d_{i}^{p}}
$$

where $d$. 1s the distance between the estimated point and the sample point, $p$ - an exponent parameter.

The choice of exponent value is known to significantly affect estimation quality (Isaaks, Srivastava, 1989; Weber, Englund, 1994). Weighting is highly dependent upon $p$, with an increase in distance resulting in an exponential decrease in weighting. This study used a power of 2 and a skewness value of $<1$ in IDW (Agris, 1998).

\begin{tabular}{|c|c|c|c|c|c|c|c|c|}
\hline Variable & Min & Max & Mean & Median & Skewness & Kurtosis & SD & CV\% \\
\hline $\mathrm{pH}$ & 7.62 & 9.33 & 8.57 & 8.53 & 0.11 & 0.04 & 0.34 & 3.97 \\
\hline $\mathrm{EC} \mathrm{dS} \mathrm{m} \mathrm{m}^{-1}$ & 0.17 & 3.49 & 0.86 & 0.65 & 1.23 & 1.20 & 0.70 & 81.08 \\
\hline Exchangeable $\mathrm{Na}$ meq $100 \mathrm{~g}^{-1}$ & 0.25 & 18.08 & 5.46 & 5.140 & 0.99 & 0.73 & 3.71 & 68.12 \\
\hline ESP \% & 0.61 & 44.31 & 15.79 & 15.16 & 0.64 & -0.30 & 10.40 & 65.84 \\
\hline
\end{tabular}

Table 1. Descriptive statistics for selected soil properties

EC - electrical conductivity, ESP - exchangeable sodium percentages, Min - minimum, Max - maximum, SD - standard deviation, $\mathrm{CV}$ - coefficient of variation

Inverse distance weighting process, result maps and cross validation results for the selected soil parameters. EC values showed the greatest variability of the different soil parameters analysed, with a $57.40 \%$ coefficient of variation. This finding was attributed to poor drainage conditions and high clay content,
The process of determination drainage efficiency using statistical analysis. The Kolmogorov-Simirnov and Levene's statistic tests were applied to test normality and homogeneity of variance, respectively. Data sets were analyzed with two-way ANOVA (the factors were six pipe regions $(1,2,3,4,5,6)$ and five soil depths $(30,60,90,120,150 \mathrm{~cm}))$ and means compared with Duncan's multiple range test. Variables were displayed as mean \pm standard error of the mean (SEM). ANOVA was performed using Minitab 15 software and means were compared using the MSTAT package program for Duncan tests. The alpha level was set at $1 \%$.

\section{Results and discussion}

Descriptive statistics result of the soil properties.

The findings of soil analysis for the parameters $\mathrm{pH}, \mathrm{EC}$, exchangeable Na and ESP are summarized in Table 1. Soil analysis showed the $\mathrm{pH}$ value of the study area ranged mainly from 7.62 to 9.33 , with the $\mathrm{pH}$ increasing with increasing depth. EC values ranged from 0.17 to $3.49 \mathrm{dS} \mathrm{m}^{-1}$. Mean values of soil parameters varied by interval, with EC ranging from 0.17 to $3.49 \mathrm{dS} \mathrm{m}^{-1}$ and ESP from $0.61 \%$ to $44.31 \%$. especially in the subsurface horizons, which restricted downward movement of water. The mean overall clay content was $61.83 \%$, with clay content ranging from a minimum of $41.15 \%$ to a maximum of $84.42 \%$. Table 2 shows descriptive statistics of selected soil properties using IDW method.

Table 2. Descriptive statistics of selected soil properties using inverse distance weighting (IDW) method

\begin{tabular}{cccccccccc}
\hline Variable & Min & Max & Mean & Median & Skewness & Kurtosis & SD & CV \% \\
\hline pH & 7.900 & 9.240 & 8.557 & 8.545 & 0.39 & 0.20 & 0.211 & 2.47 \\
EC dS m & -1 & 0.236 & 2.809 & 0.867 & 0.777 & 0.72 & -0.25 & 0.497 & 57.40 \\
Exchangeable Na meq $100 \mathrm{~g}^{-1}$ & 1.565 & 13.580 & 5.407 & 4.902 & 0.63 & -0.40 & 2.428 & 44.90 \\
ESP \% & 4.090 & 34.505 & 15.732 & 14.815 & 0.37 & -0.83 & 6.914 & 43.95 \\
\hline
\end{tabular}

Explanations under Table 1

IDW was conducted with a minimum of 3 samples, a maximum of 24 samples and a maximum radius of $30 \mathrm{~m}$. These parameters were chosen based on the size of the study area and the positions of sampling locations. Table 3 shows the weighted average values of the soil parameters among the increasing depth. All parameters values tended to increase with increasing soil depth.

Soil $\mathbf{p H}$. Figure 3 shows the spatial distribution of soil $\mathrm{pH}$ values in the study area. In the first two soil horizon layers $(0-30$ and $30-60 \mathrm{~cm}), \mathrm{pH}$ generally varied

Table 3. The weighted average values of the soil parameters among the increasing depth

\begin{tabular}{ccccc}
\hline $\begin{array}{c}\text { Depth } \\
\mathrm{cm}\end{array}$ & $\mathrm{pH}$ & $\begin{array}{c}\mathrm{EC} \\
\mathrm{dS} \mathrm{m}^{-1}\end{array}$ & $\begin{array}{c}\text { Exchangeable Na } \\
\text { meq } 100 \mathrm{~g}^{-1}\end{array}$ & $\begin{array}{c}\mathrm{ESP} \\
\%\end{array}$ \\
\hline $0-30$ & 8.312 & 0.331 & 2.729 & 7.436 \\
$30-60$ & 8.449 & 0.494 & 3.709 & 10.850 \\
$60-90$ & 8.618 & 0.812 & 4.961 & 15.541 \\
$90-120$ & 8.707 & 1.199 & 6.859 & 20.537 \\
$120-150$ & 8.700 & 1.500 & 8.778 & 24.297 \\
\hline
\end{tabular}

Explanations under Table 1 between $8.2-8.5$. In the third soil layer $(60-90 \mathrm{~cm})$ of the soil $\mathrm{pH}$ values generally varied between $8.2-8.8$. In the last two soil horizon layers (90-120 and 120$150 \mathrm{~cm}), \mathrm{pH}$ values in some places were as high as 8.8 9.3 , especially in the northern section of the study area (Fig. 3). But generally, the last two soil layers (90-120 and $120-150 \mathrm{~cm}$ ) of the $\mathrm{pH}$ values had mostly variation range between 8.5 and 8.8.
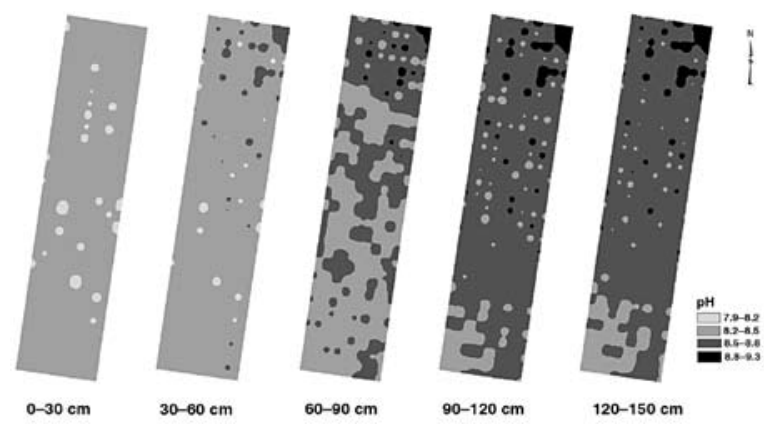

Figure 3. Soil layer mapping of estimated soil $\mathrm{pH}$ values 
Soil analysis and interpolated values for $\mathrm{pH}$ showed good correlation, particularly for up to $60 \mathrm{~cm}$, suggesting that IDW is an appropriate method for the estimation of soil $\mathrm{pH}$ as well as other soil properties. At soil depths of $90-120$ and $120-150 \mathrm{~cm}, \mathrm{pH}$ values tended to range between $8.5-8.8$, although they were higher in the northern part of the study area, reaching 8.8-9.3. At depths closer to $120 \mathrm{~cm}, \mathrm{pH}$ values tended to exceed 8.5 due to high groundwater levels and clay content, with the greatest problems found in the north. These results are in line with the findings for EC, exchangeable $\mathrm{Na}$ and ESP. Moreover, they indicate that the closed drainage network in the study area is inadequate, and that as a result, the water level has a tendency to rise above the root zone, particularly after precipitation and irrigation. Robinson and Metternicht (2005) compared the accuracy of ordinary kriging, lognormal ordinary kriging, IDW and splines for interpolating seasonally stable soil properties $(\mathrm{pH}, \mathrm{EC}$ and organic matter). The researchers indicated that IDW interpolated subsoil $\mathrm{pH}$ with the greatest accuracy and ordinary kriging performed best for the topsoil $\mathrm{pH}$ in their experimental design. It was shown that IDW interpolated both topsoil and subsoil with the greatest accuracy in this research. Also Weber and Englund (1992) found that IDW produced better results than kriging.

Electrical conductivity (EC). EC values in the two soil layers $(0-30$ and $30-60 \mathrm{~cm})$ ranged from $0.23-1.00 \mathrm{dS} \mathrm{m}^{-1}$, whereas EC values in the last two soil layers $(90-120$ and $120-150 \mathrm{~cm})$ generally ranged from 1-2 $\mathrm{dS} \mathrm{m}^{-1}$ (Fig. 4). The increase in EC values with increasing depth can be attributed to drainage problems and improper irrigation.

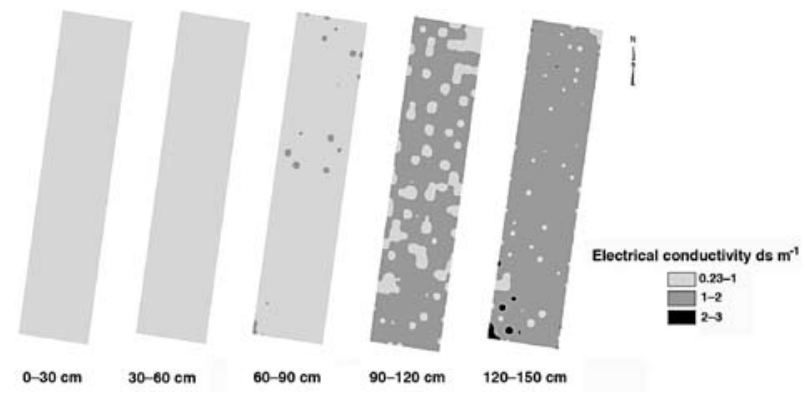

Figure 4. Soil layer mapping of estimated electrical conductivity (EC) values

Exchangeable sodium (Na). In general, exchangeable $\mathrm{Na}$ levels increased with increasing depth (Fig. 5). According to obtained data, the critical depth of sodium is $30 \mathrm{~cm}$ for plant growth. This situation is critical in terms of soil remediation, especially in the root zone, and has implications for land use planning and management. The last two soil layers (90-120 and $120-150 \mathrm{~cm}$ ) had very high exchangeable $\mathrm{Na}$ values especially in the northern section of the study area.

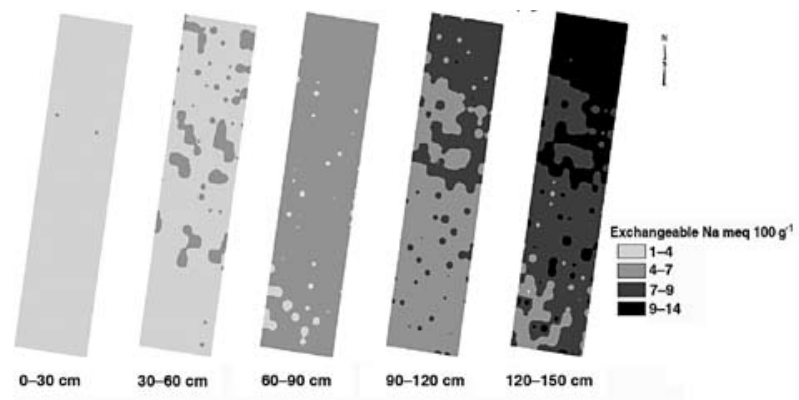

Figure 5. Soil layer mapping of estimated exchangeable sodium $(\mathrm{Na})$ values
Exchangeable sodium percentages (ESP). ESP values increased with increases in soil layer depths, especially in the northern part of the study area (Fig. 6). ESP variations were observed to parallel those of exchangeable $\mathrm{Na}$. This suggests that rather than calculating cation exchange capacity (CEC) to determine ESP values, exchangeable $\mathrm{Na}$ can be used as a parameter in IDW. It is apparent that values of all soil parameters of $\mathrm{pH}, \mathrm{EC}, \mathrm{ESP}$ and exchangeable $\mathrm{Na}$ are mainly higher in the north part of the study area. This could be explained by decreasing of the drainage efficiency in drainage pipe regions 1, 2, 3 and 4. Although drainage system is under operation at the study area, drainage pipes and pattern of the research area must be controlled for soil management practices (Halliwell et al., 2001). A new drainage pipe could be installed and designed in the study area for encountering drainage problem.

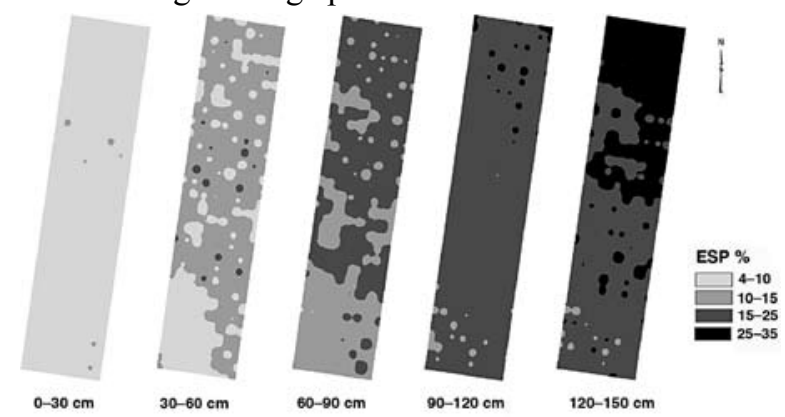

Figure 6. Soil layer mapping of estimated exchangeable sodium percentage (ESP) values

Cross validation was performed for all variables to determine the accuracy of IDW interpolation in a different depth in Table 4. In general, the results of interpolation were compatible with those of soil analysis for $\mathrm{EC}, \mathrm{pH}$, exchangeable $\mathrm{Na}$ and ESP. Of the different parameters examined, EC had the highest mean error in $120-150 \mathrm{~cm}$ depth $(9.010 \%)$, which was attributed to the variability of EC values obtained from laboratory analysis of soil samples. Exchangeable Na values had also high mean error especially $90-150 \mathrm{~cm}$ depth (8.963). Soil $\mathrm{pH}$, mean errors ranging between $0.007-0.421 \%$, had the lowest mean error values.

According to IDW soil layer maps and cross validation results, the subsurface drainage systems in the study area cannot control the watertable, limit salinization through capillary rise, and facilitate the leaching of salts. IDW interpolation is more effective when the values of points with similar depths are used in interpolation. In this study, ESP, exchangeable $\mathrm{Na}$ and EC values were generally low for shallow soil layer, with values increasing with increases in depth. For the first soil layer $(0-30 \mathrm{~cm})$, interpolated values were higher than measured values. This finding can be attributed to an increase in mean error caused by the excessive ESP in soil horizons beyond $30 \mathrm{~cm}$. A similar situation was observed between measured and interpolated values for $\mathrm{EC}$ and exchangeable $\mathrm{Na}$ values. It is likely that IDW interpolation would have been more accurate if a greater number of sample points could have been used.

The process of drainage efficiency determination. Results of the IDW data were used to evaluate drainage efficiency of the drainage pipes. Six drainage pipes were determined in the study area. The study area was divided into 6 subregions according to their effectiveness (Fig. 7). 
Table 4. Cross-validation results for four soil properties

\begin{tabular}{|c|c|c|c|c|c|}
\hline $\begin{array}{c}\text { Exchangeable } \mathrm{Na} \\
\text { meq } 100 \mathrm{~g}^{-1}\end{array}$ & MEV & MEP \% & $\begin{array}{c}\mathrm{EC} \\
\mathrm{dS} \mathrm{\textrm {m } ^ { - 1 }} \\
\end{array}$ & MEV & MEP \% \\
\hline $0-30 \mathrm{~cm}$ & 0.034 & 1.257 & $0-30 \mathrm{~cm}$ & 0.007 & 2.136 \\
\hline $30-60 \mathrm{~cm}$ & 0.180 & 4.418 & $30-60 \mathrm{~cm}$ & 0.011 & 2.100 \\
\hline $60-90 \mathrm{~cm}$ & 0.134 & 2.478 & $60-90 \mathrm{~cm}$ & 0.004 & 0.547 \\
\hline $90-120 \mathrm{~cm}$ & 0.070 & 8.963 & $90-120 \mathrm{~cm}$ & 0.006 & 0.508 \\
\hline $120-150 \mathrm{~cm}$ & 0.845 & 8.963 & $120-150 \mathrm{~cm}$ & 0.150 & 9.010 \\
\hline ESP \% & $\mathrm{MEV}$ & MEP \% & $\mathrm{pH}$ & MEV & MEP \% \\
\hline $0-30 \mathrm{~cm}$ & 1.076 & 3.870 & $0-30 \mathrm{~cm}$ & 0.002 & 0.034 \\
\hline $30-60 \mathrm{~cm}$ & 2.610 & 8.554 & $30-60 \mathrm{~cm}$ & 0.003 & 0.044 \\
\hline $60-90 \mathrm{~cm}$ & 0.325 & 1.713 & $60-90 \mathrm{~cm}$ & 0.006 & 0.007 \\
\hline $90-120 \mathrm{~cm}$ & 0.022 & 0.107 & $90-120 \mathrm{~cm}$ & 0.002 & 0.026 \\
\hline $120-150 \mathrm{~cm}$ & 0.599 & 2.905 & $120-150 \mathrm{~cm}$ & 0.036 & 0.421 \\
\hline
\end{tabular}

ESP - exchangeable sodium percentages, MEV - mean error value, MEP - mean error percent, EC - electrical conductivity

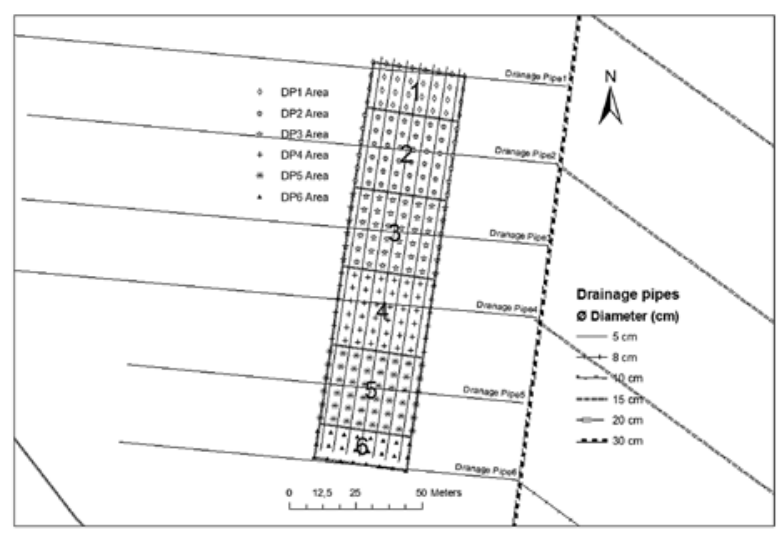

Figure 7. Drainage pipe regions of the study area

Results of analysis of variance. There were significant interactions between regions $\times$ depths for independent variables such as exchangeable $\mathrm{Na}$, ESP and $\mathrm{pH}$. Accordingly, the Duncan test results are given in Tables 5, 6 and 7. Exchangeable $\mathrm{Na}$ and ESP values increased with increasing depth in all pipe regions, this rising was found significant $(p<0.001)$. Variable $\mathrm{Na}$ values for the pipe regions detected in the order of 2,3 , 1 and 4 , respectively at a depth of $0-30 \mathrm{~cm}$ pointed out that these regions were more important than other pipe regions. Similarly, at a depth of $60-90 \mathrm{~cm}$, the increase in the values for the regions in order of 1, 3 and 2 was higher compared to that for the other regions. The rise in variable $\mathrm{Na}$ values, especially for the $1^{\text {st }}$ pipe region at a depth of 120-150 cm, was higher than the rise in values for the other regions at the same depth (Table 5). In the investigation area, the condition of higher exchangeable $\mathrm{Na}$ values for the pipe regions 1, 2, 3 and 4 compared to the values for other regions is an indication of more severe drainage problem for these regions.

Similar situation can be indicated by the results of two-way ANOVA for ESP values as shown in Table 6 . When all the pipe regions are concerned, the increase in ESP values for the regions in order of 1, 2, 3 and 4 at depths more than $60 \mathrm{~cm}$ layer of soil with a $\mathrm{p}$ value lower than 0.001 was found to be more important.

Table 5. Descriptive statistics and Duncan test results for exchangeable sodium (Na) values (meq $100 \mathrm{~g}^{-1}$ ) in five soil depths $\times$ six drainage pipe regions

\begin{tabular}{cccc}
\hline Depth cm & Pipe 1 region & Pipe 2 region & Pipe 3 region \\
\hline $0-30$ & $2.78 \pm 0.098 \mathrm{Ea}$ & $2.86 \pm 0.080 \mathrm{Ea}$ & $2.84 \pm 0.077 \mathrm{Ea}$ \\
$30-60$ & $3.81 \pm 0.164 \mathrm{Dab}$ & $3.79 \pm 0.126 \mathrm{Dab}$ & $3.95 \pm 0.139 \mathrm{Da}$ \\
$60-90$ & $5.42 \pm 0.148 \mathrm{Ca}$ & $5.16 \pm 0.130 \mathrm{Ca}$ & $5.19 \pm 0.133 \mathrm{Ca}$ \\
$90-120$ & $7.77 \pm 0.116 \mathrm{Ba}$ & $7.32 \pm 0.140 \mathrm{Bab}$ & $7.04 \pm 0.151 \mathrm{Bbc}$ \\
$120-150$ & $10.71 \pm 0.20 \mathrm{Aa}$ & $9.53 \pm 0.161 \mathrm{Ab}$ & $9.10 \pm 0.190 \mathrm{Ab}$ \\
\hline Depth cm & Pipe 4 region & Pipe 5 region & $2.47 \pm 0.092 \mathrm{Ea}$ \\
$0-30$ & $2.76 \pm 0.048 \mathrm{Ea}$ & $2.55 \pm 0.052 \mathrm{Ea}$ & $3.30 \pm 0.080 \mathrm{Db}$ \\
$60-60$ & $3.85 \pm 0.122 \mathrm{Dab}$ & $4.37 \pm 0.082 \mathrm{Dab}$ & $4.50 \pm 0.104 \mathrm{Cb}$ \\
$90-120$ & $4.92 \pm 0.107 \mathrm{Cab}$ & $6.23 \pm 0.093 \mathrm{Cb}$ & $6.14 \pm 0.183 \mathrm{Bd}$ \\
$120-150$ & $6.59 \pm 0.091 \mathrm{Bcd}$ & $7.55 \pm 0.270 \mathrm{Ad}$ & $7.42 \pm 0.370 \mathrm{Ad}$ \\
\hline
\end{tabular}

Note. Vertically, different capital letters indicate statistically significant differences among depth of measurements according to the Duncan test at the 0.01 level; horizontally, different small letters indicate statistically significant differences between the groups of pipe regions according to the Duncan test at the 0.01 level.

Table 6. Descriptive statistics and Duncan test results for exchangeable sodium percentage (ESP \%) values through in five soil depths $\times$ six drainage pipe regions

\begin{tabular}{cccc}
\hline Depth cm & Pipe 1 region & Pipe 2 region & Pipe 3 region \\
\hline $0-30$ & $7.47 \pm 0.265 \mathrm{Ea}$ & $7.70 \pm 0.225 \mathrm{Ea}$ & $7.74 \pm 0.225 \mathrm{Ea}$ \\
$30-60$ & $11.11 \pm 0.484 \mathrm{Dab}$ & $11.07 \pm 0.383 \mathrm{Dab}$ & $11.69 \pm 0.449 \mathrm{Da}$ \\
$60-90$ & $17.23 \pm 0.484 \mathrm{Ca}$ & $16.40 \pm 0.434 \mathrm{Cab}$ & $16.38 \pm 0.414 \mathrm{Cab}$ \\
$90-120$ & $23.58 \pm 0.417 \mathrm{Ba}$ & $22.14 \pm 0.451 \mathrm{Bab}$ & $21.29 \pm 0.413 \mathrm{Bbc}$ \\
$120-150$ & $29.82 \pm 0.423 \mathrm{Aa}$ & $26.61 \pm 0.460 \mathrm{Ab}$ & $25.41 \pm 0.465 \mathrm{Ab}$ \\
\hline Depth cm & Pipe 4 region & Pipe 5 region & $6.88 \pm 0.257 \mathrm{Ea}$ \\
$30-60$ & $7.55 \pm 0.144 \mathrm{Ea}$ & $7.00 \pm 0.148 \mathrm{Ea}$ & $9.70 \pm 0.268 \mathrm{Db}$ \\
$60-90$ & $11.24 \pm 0.339 \mathrm{Dab}$ & $9.80 \pm 0.241 \mathrm{Db}$ & $13.47 \pm 0.312 \mathrm{Cc}$ \\
$90-120$ & $15.53 \pm 0.328 \mathrm{Cb}$ & $18.20 \pm 0.428 \mathrm{Bd}$ & $17.38 \pm 0.546 \mathrm{Bd}$ \\
$120-150$ & $20.08 \pm 0.255 \mathrm{Bc}$ & $20.62 \pm 0.669 \mathrm{Ad}$ & $19.55 \pm 0.904 \mathrm{Ad}$ \\
\hline
\end{tabular}

Explanations under Table 5 
Table 7. Descriptive statistics and Duncan test results for $\mathrm{pH}$ values in five soil depths $\times$ six drainage pipe regions

\begin{tabular}{cccc}
\hline Depth cm & Pipe 1 region & Pipe 2 region & Pipe 3 region \\
\hline $0-30$ & $8.36 \pm 0.013 \mathrm{Ca}$ & $8.30 \pm 0.013 \mathrm{Da}$ & $8.29 \pm 0.013 \mathrm{Da}$ \\
$30-60$ & $8.51 \pm 0.032 \mathrm{Ba}$ & $8.45 \pm 0.020 \mathrm{Cab}$ & $8.44 \pm 0.016 \mathrm{Cab}$ \\
$60-90$ & $8.74 \pm 0.041 \mathrm{Aa}$ & $8.65 \pm 0.027 \mathrm{Bb}$ & $8.62 \pm 0.021 \mathrm{Bbc}$ \\
$90-120$ & $8.82 \pm 0.041 \mathrm{Aa}$ & $8.74 \pm 0.027 \mathrm{Aab}$ & $8.72 \pm 0.022 \mathrm{Abc}$ \\
$120-150$ & $8.83 \pm 0.039 \mathrm{Aa}$ & $8.75 \pm 0.023 \mathrm{Aab}$ & $8.71 \pm 0.019 \mathrm{Ab}$ \\
\hline Depth cm & Pipe 4 region & Pipe 5 region & $8.33 \pm 0.013 \mathrm{Ca}$ \\
$0-30$ & $8.30 \pm 0.016 \mathrm{Da}$ & $8.32 \pm 0.013 \mathrm{Da}$ & $8.45 \pm 0.012 \mathrm{Bab}$ \\
$60-60$ & $8.43 \pm 0.015 \mathrm{Cb}$ & $8.43 \pm 0.011 \mathrm{Cb}$ & $8.56 \pm 0.015 \mathrm{Ac}$ \\
$90-120$ & $8.59 \pm 0.018 \mathrm{Bbc}$ & $8.56 \pm 0.013 \mathrm{Bc}$ & $8.62 \pm 0.019 \mathrm{Ad}$ \\
$120-150$ & $8.70 \pm 0.017 \mathrm{Abcd}$ & $8.64 \pm 0.015 \mathrm{Acd}$ & $8.59 \pm 0.020 \mathrm{Ad}$ \\
\hline
\end{tabular}

Explanations under Table 5

According to results of analysis of variance, there were non-significant interactions between regions $x$ depths for independent variable electrical conductivity and it was found that the main factors were significant (Table 8).

Table 8. Descriptive statistics for electrical conductivity (EC) values $\left(\mathrm{dS} \mathrm{m}^{-1}\right)$ in five depths $\times$ six drainage pipe regions

\begin{tabular}{cccc}
\hline Pipe region & mean \pm SEM & $\begin{array}{c}\text { Depth } \\
\text { cm }\end{array}$ & mean \pm SEM \\
\hline 1 & $0.86 \pm 0.036 \mathrm{~B}$ & $0-30$ & $0.33 \pm 0.027 \mathbf{~ E}$ \\
2 & $0.88 \pm 0.030 \mathrm{~B}$ & $30-60$ & $0.49 \pm 0.008 \mathbf{D}$ \\
3 & $0.87 \pm 0.032 \mathrm{~B}$ & $60-90$ & $0.81 \pm 0.012 \mathbf{C}$ \\
4 & $0.83 \pm 0.031 \mathrm{~B}$ & $90-120$ & $1.20 \pm 0.018 \mathbf{B}$ \\
5 & $0.85 \pm 0.033 \mathrm{~B}$ & $120-150$ & $1.50 \pm 0.025 \mathbf{A}$ \\
6 & $0.96 \pm 0.054 \mathrm{~A}$ & & \\
\hline
\end{tabular}

Note. Capital letters indicate statistically significant differences among different pipe region and bold capital letters indicate statistically significant different depth measurements according to the Duncan test at the 0.01 level, SEM - standard error of the mean.

Considering EC, the factors of pipe region and depth were found to be important statistically $(p<0.001)$. Duncan test results performed accordingly are presented in Table 8 . The $6^{\text {th }}$ pipe region at a depth of $120-150 \mathrm{~cm}$ showed higher EC compared to other regions.

\section{Conclusions}

1. Factors that impact the relative performance of inverse distance weighting (IDW) such as minimum sample number, maximum sample number, maximum radius and size of the study area are important for sitespecific management (SSM). Some studies have found the performance of IDW to vary with changes in grid size $(0.09 \leq$ grid size $\leq 4.0$ ha) (Hosseini et al., 1994; Weisz, 1995; Mueller et al., 2001). However, the most significant effect on IDW performance and accuracy is the proximity in location and depth of the known soil parameters such as exchangeable sodium percentages (ESP), exchangeable sodium $(\mathrm{Na}), \mathrm{pH}$ and electrical conductivity $(\mathrm{EC})$ values used in interpolation. Our study area is $4500 \mathrm{~m}^{2}(150 \times$ 30) and there was a good relationship between known soil parameters' (such as pH, EC, ESP, exchangeable Na) depth and interpolation results.

2. This study found the majority of data with low skewness values to provide the best results with a power of 2. In general, the exchangeable $\mathrm{Na}$ of the soil samples in this study was greatest at depths of $45-50 \mathrm{~cm}$ as a result of poor drainage and high clay content (approx. 45\%). Measured and estimated values for other soil properties - pH, EC, ESP, and cation exchange capacity (CEC) were also found to increase with increasing depth.
Overall, the data obtained from our study can be used for SSM, such as testing the performance of irrigation and drainage systems and evaluating land-use practices.

\section{Acknowledgements}

This project received support from the Ankara University Scientific Research Coordination Office (Project No. 09 B 4347001). The authors also thank Dr. Yeliz Kaşko Arıcı for the statistic evaluation. Finally, the authors value the constructive comments of two anonymous reviewers as they significantly improved the quality of the final manuscript.

Received 12072012

Accepted 05022013

\section{References}

Agris. 1998. AGLink reference manual, version 5.3. Roswell, USA, p. 147-171

Burrough P. A., McDonnell R. A. 1998. Principles of geographic information systems. Oxford, UK, $333 \mathrm{p}$.

Franzen D. W., Peck T. R. 1995. Field soil sampling density for variable rate fertilization. Journal of Production Agriculture, 8: 568-574 http://dx.doi.org/10.2134/jpa1995.0568

Gotway C. A., Ferguson R. B, Hergert G. W, Peterson T. A. 1996. Comparison of kriging and inverse-distance methods for mapping soil parameters. Soil Science Society of America Journal, 60: 1237-1247 http://dx.doi. org/10.2136/sssaj1996.03615995006000040040x

Halliwell D. J., Barlow K. M., Nash D. M. 2001. A review of the effects of wastewater sodium on soil physical properties and their implications for irrigation systems. Australian Journal of Soil Research, 39 (6): 1259-1267 http://dx.doi.org/10.1071/SR00047

Hosseini E., Gallichand D., Marcotte D. 1994. Theoretical and experimental performance of spatial interpolation methods for soil salinity analysis. Transactions of the American Society of Agricultural Engineers, 37: 1799-1807

Isaaks E. H., Srivastava R. M. 1989. An introduction to applied geostatistics. New York, USA, 561 p.

Kerry R., Oliver M. A. 2004. Average variograms to guide soil sampling for land management. The International Journal of Applied Earth Observation and Geoinformation, 5: 307-325 http://dx.doi.org/10.1016/j.jag.2004.07.005

Kravchenko A. N. 2003. Influence of spatial structure on accuracy of interpolation methods. Soil Science Society of America Journal. 67: 1564-1571 http://dx.doi.org/10.2136/sssaj2003.1564

Kravchenko A. N., Bullock D. G. 1999. A comparative study of interpolation methods for mapping soil properties. Agronomy Journal. 91 (3): 393-400 http://dx.doi.org/10.2134/agronj1999.00021962009100030007x

Kollias V. J., Kalivas D. P., Yassoglou N. J. 1999. Mapping the soil resources of a recent alluvial plain in Greece using fuzzy sets in a GIS environment. European Journal of Soil Science. 50: 261-273

http://dx.doi.org/10.1046/j.1365-2389.1999.t01-1-00231.x 
Kumova Y., YarpuzluA. 1987. Drenaj Boru ve ZarfMalzemelerinin Arazi Koșullarında Karșılaştırılması. T. C. Tarım Orman ve Köyișleri Bakanlığı Köy Hizmetleri Genel Müdürlüğü, Tarsus Araştırma Enstitüsü Müdürlüğü Yayınları. Genel Yayın No. 140, Rapor Seri No. 81 (in Turkish)

Laslett G. M., McBratney A. B., Pahl P. J., Hutchinson M. F. 1987. Comparison of several spatial prediction methods for soil $\mathrm{pH}$. Journal of Soil Science. 38: 325-341 http://dx.doi.org/10.1111/j.1365-2389.1987.tb02148.x

Lu G. Y., Wong D. W. 2008. An adaptive inverse-distance weighting spatial technique. Computer Geoscience. 34: 1044-1055 http://dx.doi.org/10.1016/j.cageo.2007.07.010

Mueller T. G., Pierce F. J., Schabenberger O., Warncke D. D. 2001. Map quality for site-specific fertility management Soil Science Societv of America Journal. 65: 1547-1558 http://dx.doi.org/10.2136/sssaj2001.6551547x

Nalder I. A., Wein R. W. 1998. Spatial interpolation of climatic normals: test of a new methods in the Canadian boreal forest. Agricultural and Forest Meteorologv. 92: 211-225 http://dx.doi.org/10.1016/S0168-1923(98)00102-6

Olea R. A. 1999. Geostatistics for engineers and earth science. London. UK. $480 \mathrm{p}$ http://dx.doi.org/10.1007/978-1-4615-5001-3

Panagopoulos T., Jesus J., Antunes M. D. C., Beltrao J. 2006. Analysis of spatial interpolation for optimizing management of a salinized field cultivated with lettuce. European Journal of Agronomy. 24 (1): 1-10 http://dx.doi.org/10.1016/j.eja.2005.03.001

Redulla C. A., Havlin J. L., Kluitenberg G. L., Zhang N., Shrock M. D. 1996. Variable nitrogen management for improving groundwater quality: proceedings of the $3^{\text {rd }}$ International Conference on Precision Agriculture. Robert P. C. et al. (eds). American Society of Agronomy. Madison, USA, p. 1101-1110

Robinson T. P., Metternicht G. 2005. Testing the performance of spatial interpolation techniques for mapping soil properties. Computers and Electronics in Agriculture, 2 (50): $97-108$
Schloeder C. A. Zimmerman N. E., Jacobs M. J. 2001. Comparison of methods for interpolating soil properties using limited data. Soil Science Society of America Journal. 65: 470-479 http://dx.doi.org/10.2136/sssaj2001.652470x

Thomas G. W. 1982. Exchangeable cations. Methods of soil analysis. Part II. Chemical and microbiological properties ASA-SSSA. Madison, USA, p. 159-165

Thornthwaite C. W. 1948. An approach toward a rational classification of climate. Geographical Review, 38: 55-94 http://dx.doi.org/10.2307/210739

Tunçay T. 2010. Kapalı drenaj sisteminin etkinliğinde rol oynayan toprak özelliklerinin konumsal değişiminin belirlenmesi: PhD Thesis. Ankara University, Soil Science and Plant Nutrion Department. Ankara, Turkey, p. 279 (in Turkish)

Voltz M., Webster R. 1990. A comparison of kriging, cubic splines and classification for predicting soil properties from sample information. Journal of Soil Science, 41: 473-490 http://dx.doi.org/10.1111/j.1365-2389.1990.tb00080.x

Weber D. D., Englund E. J. 1992. Evaluation and comparison of spatial interpolators. Mathematical Geology, 24: 381-391 http://dx.doi.org/10.1007/BF00891270

Weber D. D., Englund E. J. 1994. Evaluation and comparison of spatial interpolation II. Mathematical Geology, 26: 589 603 http://dx.doi.org/10.1007/BF02089243

Webster R., Oliver M. A. 2001. Geostatistic for environmental sciences. Brisbane, Australia, $398 \mathrm{p}$.

Weisz R. 1995. Map generation in high-value horticultural integrated pest management: appropriate interpolation methods for site-specific pest management of Colorado potato beetle (Coleoptera: Chrysomelidae). Journal of Economic Entomology. 88: 1650-1657

Wenjio S., Jiyuan L., Zhengping D., Yinjun S., Chuanfa C., Tianxiang Y. 2009. Surface modeling of soil $\mathrm{pH}$. Geoderma, 150: $113-119$ http://dx.doi.org/10.1016/j.geoderma.2009.01.020

ISSN 1392-3196 / e-ISSN 2335-8947

Zemdirbyste-Agriculture, vol. 100, No. 2 (2013), p. 213-219

DOI $10.13080 / \mathrm{z}-\mathrm{a} .2013 .100 .028$

\title{
Dirvožemio savybių erdvinis kitimas: atvejo studija Seyhan žemupio baseine Turkijoje
}

\author{
T. Tunçay ${ }^{1}$, İ. Bayramin ${ }^{2}$, A. Erhan Tercan ${ }^{3}$, İ. Ünver ${ }^{2}$ \\ ${ }^{1}$ Ankaros universiteto Žemès mokslų ir taikomujų tyrimų centras, Turkija \\ ${ }^{2}$ Ankaros universiteto Dirvožemio mokslo ir augalų mitybos skyrius, Turkija \\ ${ }^{3}$ Ankaros Hacettepe universiteto Kalnakasybos inžinerijos skyrius, Turkija
}

\section{Santrauka}

Tyrimo tikslas - îvertinti uždaros drenažo sistemos Seyhan žemupio baseine Çukurovoje, Turkijoje, darbą, matuojant dirvožemio savybių erdvinị kitimą. Tyrimo teritorijoje buvo parinkti septyni lygiagretūs skersiniai 150 m ilgio pjūviai su $5 \mathrm{~m}$ intervalais ir paimti 104 dirvožemio mėginiai, kuriu nustatytas $\mathrm{pH}$, elektrinis laidumas, mainų natrio (Na) kiekis ir procentas. Rezultatai apdoroti naudojant atvirkštinę atstumų svorio interpoliaciją. Elektrinio laidumo, $\mathrm{pH}$ ir mainu Na procento vertés, gautos atlikus atvirkštinę atstumu svorio interpoliacija, atitiko dirvožemio analizių rezultatus. Siekiant nustatyti interpoliacijos metodo tikslumą, atliktas patikimumo tyrimas. Elektrinio laidumo verčių interpoliacija $120-150 \mathrm{~cm}$ gylyje parodè didelę vidutinę paklaidą $(9,010 \%)$, kurios priežastimi laikytos prastos drenažo sąlygos. Nustatyta, kad atvirkštinès atstumų svorio interpoliacijos tikslumui turi ịtakos mažiausias ir didžiausias mèginių skaičius, maksimalus spindulys ir galia. Dirvožemio sekliuose horizontuose mainu Na procento, mainu Na, elektrinio laidumo vertès buvo mažos, didèjant dirvožemio gyliui jos didejjo. Duomenų rinkiniai buvo išanalizuoti taikant dviejų veiksnių (pirmasis - šešių uždarų drenažo sistemu regionas (1-6), antrasis - penki dirvožemio gyliai $(30,60,90,120,150 \mathrm{~cm}))$ ANOVA analizę, vidurkiai buvo palyginti pagal Dunkano kriteriju. Nustatyta, kad drenažo sistemos efektyvumas 1, 2, 3 ir 4 regionuose gali sumažèti greičiau, lyginant su kitais regionais.

Reikšminiai žodžiai: atvirkštinis atstumų svoris, Çukurova (Turkija), erdvinis kitimas, uždara drenažo sistema. 